\title{
MICROSTRUCTURAL ASPECTS OF THERMALLY MODIFIED Eucalyptus grandis WOOD
}

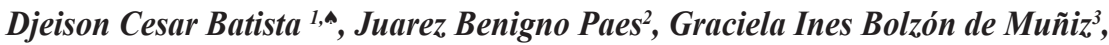 \\ Silvana Nisgoski ${ }^{3}$, José Tarcísio da Silva Oliveira ${ }^{2}$
}

\begin{abstract}
Thermal modification of wood is a process that has drawn considerable attention of Brazilian researchers, but studies about the effect of this process on wood anatomy are scarce, even in the worldwide literature. The aim of this work was to perform a preliminary analysis of the effect of the Brazilian thermal modification process called VAP HolzSysteme ${ }^{\circledR}$ on the cell dimensions of Eucalyptus grandis wood. The investigated treatments corresponded to three final cycle temperatures $\left(140,160\right.$ and $\left.180^{\circ} \mathrm{C}\right)$, which were compared to untreated wood. Wood anatomy was analyzed qualitatively and quantitatively by scanning electron microscopy (SEM) and optical microscopy, in the latter case to measure the dimensions of fibers, vessel elements and ray parenchyma. The qualitative analysis using SEM indicated that no significant changes occurred on the structure of ray parenchyma, vessels and fibers tissues. Even tyloses was preserved in the vessel elements of thermally modified wood at the highest temperature $\left(180^{\circ} \mathrm{C}\right)$. Likewise, no quantitative changes were observed in the dimensions of fibers, vessels diameter and ray parenchyma height.
\end{abstract}

Keywords: Fiber dimension, ray parenchyma, thermal modification, vessel diameter, wood structure.

\section{INTRODUCTION}

Knowledge of the anatomy and chemistry of wood is fundamental to determine its uses as engineering material, because these characteristics influence its durability, physical and mechanical properties (Tsoumis 1991, Winandy and Rowell 1984).

The main benefits imparted to wood by thermal modification are improved dimensional stability and durability, which are basically explained by chemical modifications in cell wall structures. Abundant literature can be found about this process's effect on wood's chemical composition, but the same cannot be said about anatomy (Awoyemi and Jones 2011). Of the few studies about the cell dimensions of thermally modified wood (Andersson et al. 2005, Awoyemi and Jones 2011, Bakar et al. 2003, Boonstra et al. 2006a, 2006b, Hietala et al. 2002), none has focused on eucalyptus, which is forest species planted the most in Brazil.

Studies using different methods have presented the same conclusion for thermally modified Pinus sylvestris wood, where thermal modification did not change the anatomical microstructure (Andersson et al. 2005) or the cell dimensions compared to control samples (Hietala et al. 2002). Microscopic analysis of vessels, fibers, parenchyma and rays of Grevillea robusta also indicated that the anatomical structure of wood was not significantly affected by thermal treatment (Mburu et al. 2007).

\footnotetext{
${ }^{1}$ Professor of the Department of Forest and Wood Sciences, Federal University of Espírito Santo, Espírito Santo, Brazil.

${ }^{2}$ Professor of the Department of Forest and Wood Sciences, Federal University of Espirito Santo. Espírito Santo, Brazil.

${ }^{3}$ Professor of the Department of Forest Engineering and Technology, Federal University of Paraná, Curitiba, Paraná, Brazil

-Corresponding author: djeison.batista@ufes.br

Received: 09.04.2014 Accepted: 24.10.2014
} 
Important quantities of extractives deposited in the vessels of Grevillea robusta disappeared after thermal modification, resulting in a decrease in their quantity from 5,2 to 1,6\% (Mburu et al. 2007). In another study the ray parenchyma cells of untreated Fagus sylvatica wood were clean and open, but a brown-red extractive appeared after thermal modification (Boonstra et al. 2006b).

The effect of thermal modification on Thuja plicata wood anatomy was different from those of the studies mentioned before. It resulted in destruction of tracheid walls and ray tissues, pit deaspiration and increased size of the pits (Awoyemi and Jones 2011). Other studies have also revealed that thermal modification causes changes in wood microstructure, which are strongly associated with the species and the characteristics of the process. But the major changes are a result of drying defects (such as collapse and cracks), caused by the drying stresses provoked by the drastic water removal (Boonstra et al. 2006a, 2006b).

Collapse was also observed to some extent in the structure of Quercus rubra, Juniperus virginiana and Hevea brasiliensis wood after thermal modification at $190{ }^{\circ} \mathrm{C}$ for eight hours. In this situation, the authors reported collapsed cells, wood plasticization and mass loss, with consequent loss of mechanical resistance, causing closing of the lumens (Bakar et al. 2013).

The aim of this study was to analyze the effect of the Brazilian thermal modification process VAP HolzSysteme ${ }^{\circledR}$ on the anatomy of Eucalyptus grandis wood anatomy.

\section{MATERIAL AND METHODS}

\section{Wood material and sampling}

Two plain sawn boards, free of defects, of Eucalyptus grandis W.Hill ex Maiden juvenile wood were sawn into shorter boards $(30 \times 200 \times 1,100 \mathrm{~mm})$, according to figure 1 . After this, the boards were thermally modified using the Brazilian process VAP HolzSysteme ${ }^{\circledR}$, at three final cycle temperatures $(140,160$ and 180 $\left.{ }^{\circ} \mathrm{C}\right)$. The experiment was carried out at the company TWBrazil, located in Ponta Grossa, Paraná.

The process is hygrothermal and divided into five phases. The first four last about eight hours and the fifth phase (cooling) takes approximately eight more hours. A diagram of a theoretical program is presented in figure 2, with final cycle temperature of $160^{\circ} \mathrm{C}$. The pressure is not presented in figure 2 , but it increases with temperature and reaches from 0,3 to $1,0 \mathrm{MPa}$ in phase four, depending on the final temperature.

Board 1

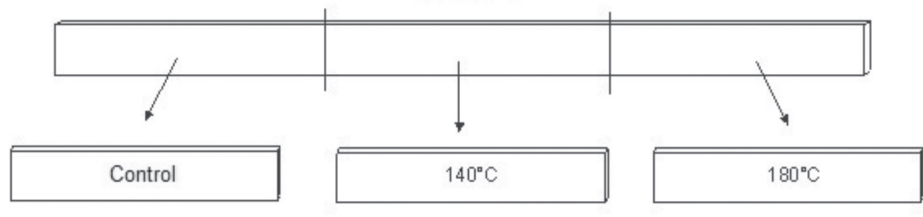

Board 2

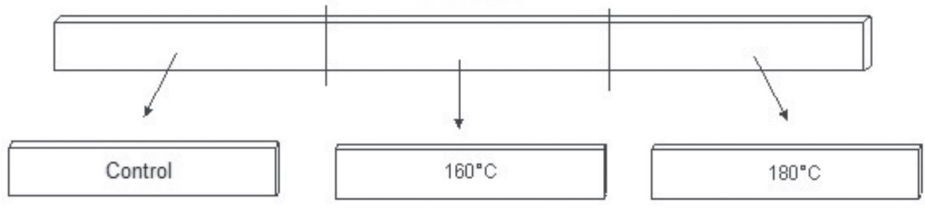

Figure 1. Sampling according to the thermal treatments. 


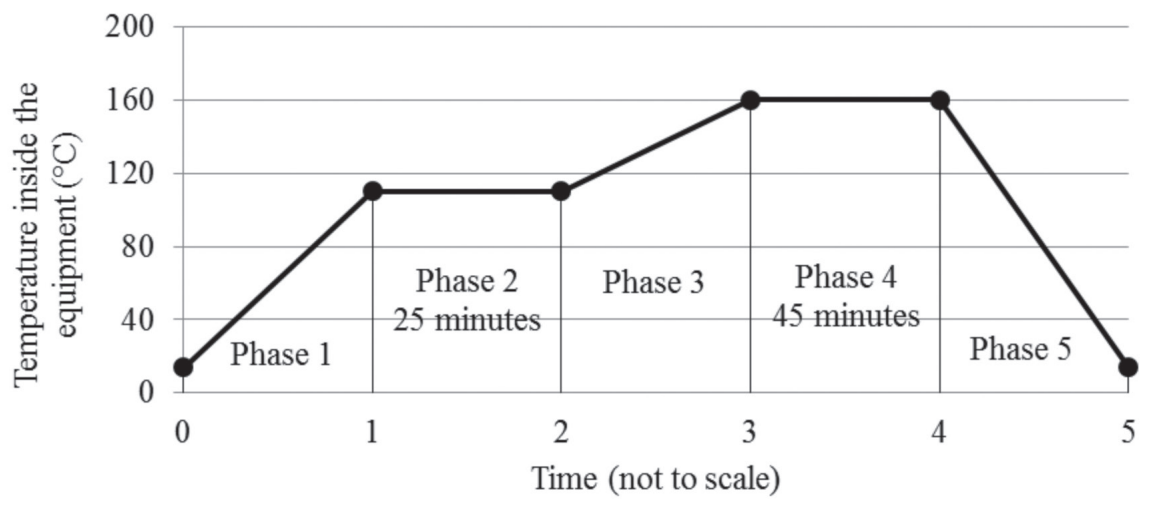

Figure 2. Example of a typical theoretical process.

A brief description of each phase shown in figure 2 follows:

Phase 1 - Initial heating: this phase corresponds to the beginning of the process, after the lumber is loaded and the cylinder is closed. Steam is injected and the system is heated, according to a predetermined heating rate $\left({ }^{\circ} \mathrm{C} \cdot \mathrm{min}^{-1}\right)$. The duration of this phase is variable and depends on the heating rate adopted.

Phase 2 - Constant temperature: after the initial heating, a constant temperature of $110{ }^{\circ} \mathrm{C}$ is maintained for 25 minutes, so the heating rate is null in this phase.

Phase 3 - Secondary heating: this is the second phase of heating, and lasts until the system reaches the final cycle temperature, according to a determined heating rate $\left({ }^{\circ} \mathrm{C} \cdot \mathrm{min}^{-1}\right)$.

Phase 4 - Thermal modification: in this phase the thermal modification of the wood occurs, and the final cycle temperature is kept constant for 45 minutes.

Phase 5 - Cooling: after phase 4, the device is turned off and the system cools down.

\section{Wood anatomical investigations}

After thermal modification, an oriented block $(10 \times 15 \times 20 \mathrm{~mm}$, respectively radial, tangential and axial $)$ was taken from each short board, at the position of the middle ray in the outer annual growth ring of the transversal section. First, the blocks were directly analyzed (without any special preparation) by scanning electron microscopy (SEM) using a Hitachi TM100 microscope to verify possible changes in wood structure.

Fibers, vessels and ray parenchyma were measured by optical microscopy, and 25 repetitions were done for each kind of cell per wood block, according to the recommendations of the International Association of Wood Anatomists (IAWA 1989). Macerations were prepared with hydrogen peroxide/acetic acid according to the method of Nicholls and Dadswell 1962, and the fibers were stained with safranin and mounted with distilled water and glycerin (1:1) on temporary slides. Individual fibers were photographed with a digital camera (7.1 megapixels) coupled to an optical microscope and the photomicrographs were used for fiber measurement (length, diameter, lumen diameter and wall thickness) using the Axiovision 4.5 software.

Transversal and tangential sections were taken, respectively, to measure the vessels and ray parenchyma, mounted with distilled water and glycerin (1:1) on temporary slides. The sections were obtained with a sliding microtome and were 18 to $20 \mu \mathrm{m}$ thick for untreated wood and the samples treated at $140{ }^{\circ} \mathrm{C}$, and 30 to $35 \mu \mathrm{m}$ for the samples treated at 160 and $180^{\circ} \mathrm{C}$. Width and height were measured for ray parenchyma and diameter for vessels, using the same equipment and method described for fiber measurement. 


\section{Statistical analysis}

The experimental design was completely randomized, with a 95\% confidence level for all tests. Bartlett's test was performed to check for homogeneity of variances among treatments (Ribeiro -Júnior 2001). In cases where homogeneity was found, analysis of variance (ANOVA) was applied, while if there was a statistically significant difference between averages (P-value $<0,05$ ), Tukey's multiple range test was performed to determine which averages were different.

If at least one of the variances was not statistically equal, the Kruskal-Wallis H-test was performed, which is a non-parametric method for ANOVA, for classification of a criterion or experiments with one factor, where generalizations can be made (Spiegel 1994).

\section{RESULTS AND DISCUSSION}

Thermally modified wood at 140,160 and $180^{\circ} \mathrm{C}$ was compared to untreated samples and no significant changes were noted in the structure of the fibrous and parenchymatous tissues, what can influence mechanical resistance, for example, as can be seen in figure 3.
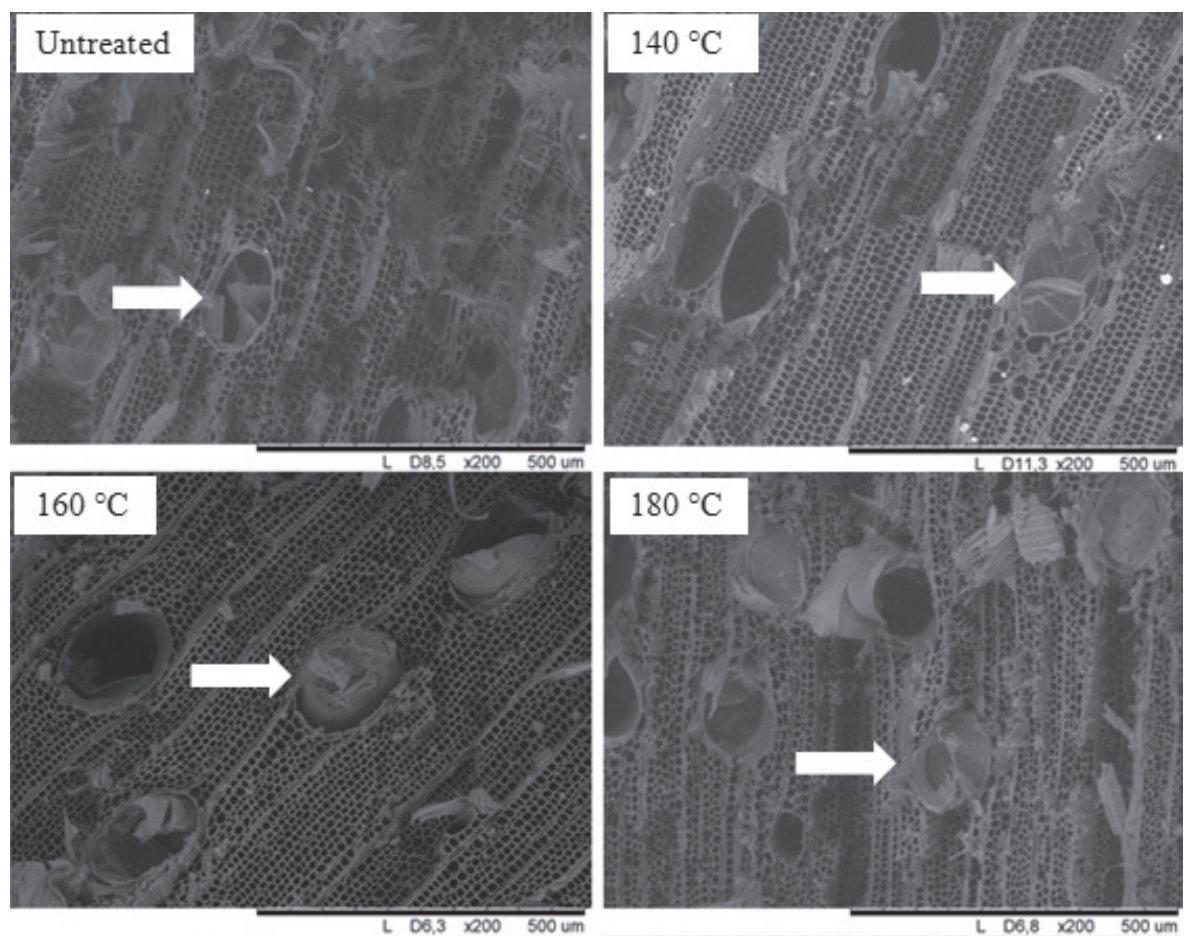

Figure 3. SEM images of transversal section of untreated Eucalyptus grandis wood and samples thermally modified at 140,160 and $180^{\circ} \mathrm{C}$. (Arrows indicate tylosis in vessels).

Tyloses remained in the vessel elements of thermally modified wood, even at the highest temperature (180 $\left.{ }^{\circ} \mathrm{C}\right)$. This indicates that possible changes in wood permeability arising from the thermal modification process are not related to changes in vessel permeability. However, it is known that cell walls become more porous (or less dense) because of mass loss, which can be a subject for further investigation about the permeability of thermally modified wood (Boonstra et al. 2006a, 2006b, Lengowski 2011, Mburu et al. 2007, Winandy and Rowell 1984).

The fibers' dimensions were not influenced by the thermal modification process, according to the data presented in table 1 . 
Table 1. Statistical analysis of fiber dimensions after different treatments.

\begin{tabular}{|c|c|c|c|c|}
\hline Treatment & $\begin{array}{c}\begin{array}{c}\text { Length } \\
(\mu \mathrm{m})\end{array} \\
\end{array}$ & $\begin{array}{c}\text { Fiber diameter } \\
(\mu \mathrm{m})\end{array}$ & $\begin{array}{c}\text { Lumen } \\
\text { diameter }(\mu \mathrm{m})\end{array}$ & $\begin{array}{c}\text { Wall thickness } \\
(\mu \mathrm{m})\end{array}$ \\
\hline \multicolumn{5}{|c|}{ Board 1} \\
\hline Untreated wood & $\begin{array}{c}1061 \\
(18 \%)\end{array}$ & $\begin{array}{l}20,94 \\
(15 \%)\end{array}$ & $\begin{array}{l}12,16 \\
(24 \%)\end{array}$ & $\begin{array}{c}4,39 \\
(23 \%)\end{array}$ \\
\hline $140^{\circ} \mathrm{C}$ & $\begin{array}{l}1201 \\
(20 \%)\end{array}$ & $\begin{array}{l}21,94 \\
(12 \%)\end{array}$ & $\begin{array}{l}13,67 \\
(18 \%)\end{array}$ & $\begin{array}{c}4,13 \\
(18 \%)\end{array}$ \\
\hline $180^{\circ} \mathrm{C}$ & $\begin{array}{c}1097 \\
(15 \%)\end{array}$ & $\begin{array}{l}21,34 \\
(17 \%)\end{array}$ & $\begin{array}{l}13,30 \\
(24 \%)\end{array}$ & $\begin{array}{c}4,02 \\
(26 \%)\end{array}$ \\
\hline Bartlett's test & $1,05^{\text {ns }}$ & $1,04^{\text {ns }}$ & $1,02^{\text {ns }}$ & $1,04^{\text {ns }}$ \\
\hline ANOVA -F-test & $2,98^{\mathrm{ns}}$ & $0,55^{\mathrm{ns}}$ & $0,18^{\mathrm{ns}}$ & $0,96^{\mathrm{ns}}$ \\
\hline \multicolumn{5}{|c|}{ Board 2} \\
\hline Untreated wood & $\begin{array}{c}1179 \\
(13 \%)\end{array}$ & $\begin{array}{l}20,33 \\
(16 \%)\end{array}$ & $\begin{array}{l}11,17 \\
(27 \%)\end{array}$ & $\begin{array}{c}4,58 \\
(19 \%)\end{array}$ \\
\hline $160^{\circ} \mathrm{C}$ & $\begin{array}{c}1067 \\
(19 \%)\end{array}$ & $\begin{array}{l}21,32 \\
(15 \%)\end{array}$ & $\begin{array}{l}11,94 \\
(21 \%)\end{array}$ & $\begin{array}{c}4,69 \\
(22 \%)\end{array}$ \\
\hline $180^{\circ} \mathrm{C}$ & $\begin{array}{c}1123 \\
(16 \%) \\
\end{array}$ & $\begin{array}{l}22,93 \\
(23 \%) \\
\end{array}$ & $\begin{array}{l}14,59 \\
(31 \%) \\
\end{array}$ & $\begin{array}{c}4,17 \\
(22 \%)\end{array}$ \\
\hline Bartlett's test & $1,03^{\mathrm{ns}}$ & $1,13^{*}$ & $1,12 *$ & $1,01^{\mathrm{ns}}$ \\
\hline ANOVA - F-test & $2,26^{\mathrm{ns}}$ & - & - & $1,91^{\mathrm{ns}}$ \\
\hline H-test & - & $2,67^{\mathrm{ns}}$ & $5,77^{\mathrm{ns}}$ & - \\
\hline
\end{tabular}

Numbers in parentheses correspond to the coefficient of variation. ns: not statistically significant and $*$ statistically significant ( $95 \%$ confidence level).

According to the Bartlett test results presented in table1, the variances of the treatments were homogeneous for all fiber dimensions of board 1, enabling the application of ANOVA. According to the F-test results, fiber dimensions of the different treatments were not statistically different, indicating that the effect of the thermal modification process was null.

On the other hand, in board 2, the Bartlett test results indicated that the variances of the treatments were not homogeneous for fiber diameter and lumen diameter. So, the H-test was applied and the results indicated that the medians of the treatments were not statistically different with $95 \%$ of confidence level.

Thermally modified wood at 160 and $180^{\circ} \mathrm{C}$ became too brittle to obtain microtome sections of transversal faces, which precluded analysis of the vessels' dimensions among treatments. Vessel measurement was only possible for the untreated samples and those treated at $140{ }^{\circ} \mathrm{C}$, in both cases taken from board 1 . Table 2 presents the results of these treatments.

Table 2.Vessel diameter of untreated and thermally modified samples at $140^{\circ} \mathrm{C}$.

\begin{tabular}{c|c|c}
\hline \multirow{2}{*}{ Treatment } & \multicolumn{2}{|c}{ Vessel diameter } \\
\cline { 2 - 3 } & Average $(\boldsymbol{\mu m})$ & Coefficient of variation $(\%)$ \\
\hline Untreated wood & 115,94 & 29,29 \\
\hline $140^{\circ} \mathrm{C}$ & 127,06 & 32,28 \\
\hline
\end{tabular}

Since only two treatments were assessed in this situation, the statistical analysis was different from that presented before. The F-test was applied ( $95 \%$ confidence level) to compare the standard deviations of the treatments and the result indicated they were homogeneous $\left(\mathrm{Fc}=0,69^{\mathrm{ns}}\right)$. Furthermore, the $\mathrm{t}$-test was applied ( $95 \%$ confidence level) to compare averages between the treatments and the result $\left(\mathrm{tc}=-1,04^{\mathrm{ns}}\right)$ showed they were not statistically different, which means that the effect of thermal modification process at $140{ }^{\circ} \mathrm{C}$ was not significant on the vessels' diameter.

Concerning analysis of ray dimensions, treatment temperature had an effect only on cell width (Table 3 ). 
Table 3. Statistical analysis of ray dimensions after different thermal treatments.

\begin{tabular}{|c|c|c|}
\hline \multirow[t]{2}{*}{ Treatment } & \multicolumn{2}{|c|}{ Ray parenchyma } \\
\hline & Height ( $\mu \mathrm{m})$ & Width $(\mu \mathrm{m})$ \\
\hline \multicolumn{3}{|c|}{ Board 1} \\
\hline Untreated wood & $\begin{array}{c}269,82 \\
(46 \%)\end{array}$ & $\begin{array}{c}13,42 \\
(31 \%)\end{array}$ \\
\hline $140^{\circ} \mathrm{C}$ & $\begin{array}{c}295,43 \\
(40 \%)\end{array}$ & $\begin{array}{l}11,80 \\
(26 \%)\end{array}$ \\
\hline $180^{\circ} \mathrm{C}$ & $\begin{array}{c}267,43 \\
(37 \%)\end{array}$ & $\begin{array}{c}9,90 \\
(22 \%)\end{array}$ \\
\hline Bartlett's test & $1,02^{\text {ns }}$ & $1,15^{* *}$ \\
\hline ANOVA -F-test & $0,46^{\mathrm{ns}}$ & - \\
\hline H-test & - & $13,33 * *$ \\
\hline \multicolumn{3}{|c|}{ Board 2} \\
\hline Untreated wood & $\begin{array}{c}230,91 \\
(31 \%)\end{array}$ & $\begin{array}{l}10,51 \\
(27 \%)\end{array}$ \\
\hline $160^{\circ} \mathrm{C}$ & $\begin{array}{c}234,16 \\
(35 \%)\end{array}$ & $\begin{array}{l}10,10 \\
(23 \%)\end{array}$ \\
\hline $180^{\circ} \mathrm{C}$ & $\begin{array}{c}288,24 \\
(40 \%)\end{array}$ & $\begin{array}{c}9,63 \\
(17 \%)\end{array}$ \\
\hline Bartlett's test & $1,08^{\text {ns }}$ & $1,11^{*}$ \\
\hline ANOVA-F-test & $3,10^{\mathrm{ns}}$ & - \\
\hline H-test & - & $0,64^{\mathrm{ns}}$ \\
\hline
\end{tabular}

Numbers in parentheses correspond to the coefficient of variation. ns: not statistically significant (95\% confidence level).*Statistically significant $(95 \%$ confidence level). $* *$ Statistically significant $(99 \%$ confidence level).

According to the results of Bartlett's test presented in table 3, the variances were homogeneous (95\% confidence level) only for the results of ray parenchyma height, enabling ANOVA. According to the F-test result, the averages of ray parenchyma height were homogeneous among the treatments.

On the other hand, the variances of ray parenchyma width were not homogeneous and ANOVA test was not possible. The H-test was applied to analyze the medians and the result indicated they were statistically different ( $99 \%$ confidence level) among the treatments.

The averages of ray parenchyma width decreased significantly because of the effect of the thermal modification process. The untreated wood had the highest average $(13,42 \mu \mathrm{m})$ and the wood treated at $180^{\circ} \mathrm{C}$ had the smallest one $(9,90 \mu \mathrm{m})$. As described before, published information about the anatomy of thermally modified wood is scarce, so it is not possible to affirm that the main cause of the decrease in ray parenchyma width was thermal modification or wood shrinkage.

It is important to note that the ray parenchyma width of wood is measured in tangential sections, where the greatest shrinkage occurs (Tsoumis 1991), and the wood samples treated at 140 and $180{ }^{\circ} \mathrm{C}$ lost more bound water than the untreated wood, leading to higher shrinkage (Bowyer et al. 2007) and smaller cell dimensions.

The behavior of ray parenchyma height of board 2 was the same as for board 1, as previously discussed. The inferences from the results of ray parenchyma width become stronger when the results of board 2 are also analyzed. The medians of ray parenchyma width were not statistically different among treatments according to the H-test ( $95 \%$ confidence level). There was a similar tendency in both boards (ray parenchyma width decreased as treatment temperature increased), but for board 2 the difference was not statistically significant while it was for board 1 . 


\section{CONCLUSIONS}

The qualitative analysis using SEM indicated that no significant changes occurred in the structure of ray parenchyma, vessels and fibers tissues. Even tyloses were preserved in the vessel elements of thermally modified wood at the highest processing temperature $\left(180^{\circ} \mathrm{C}\right)$.

Likewise, no quantitative changes were observed in the dimensions of fibers, vessels diameter and ray parenchyma heights. The effect of thermal modification on ray parenchyma width requires further investigation.

\section{ACKNOWLEDGEMENTS}

The first author would like to thank CAPES - Coordenação de Aperfeiçoamento de Pessoal de Nivel Superior (Office to Coordinate Improvement of University Personnel) for the research grant.

\section{REFERENCES}

Andersson, S; Serimaa, R; Väänänen, T; Paakkari, T; Jämsä, S; Viitaniemi; P. 2005. X-ray scattering studies of thermally modified Scots pine (Pinus sylvestris L.). Holzforschung 59 (4): 422-427.

Awoyemi, L; Jones, I.P. 2011. Anatomical explanations for the changes in properties of western red cedar (Thuja plicata) wood during heat treatment. Wood Science and Technology 45 (2): 261-267.

Bakar, B.F.A.; Hiziroglu, S.; Tahir, P.M. 2013. Properties of some thermally modified wood species. Materials and Design 43: 348-355.

Boonstra, M.J.; Rijsdijk, J.F.; Sander, C.; Kegel, B.; Tjeerdsma, B.; Militz, H. 2006a. Microstructural and physical aspects of heat treated wood, Part 1: Softwoods. Maderas. Ciencia y Tecnología 8 (3): 193-208.

Boonstra, M.J.; Rijsdijk, J.F.; Sander, C.; Kegel, B.; Tjeerdsma, B.; Militz, H. 2006b. Microstructural and physical aspects of heat treated wood, Part 2: Hardwoods. Maderas. Ciencia y Tecnología 8 (3): 209-217.

Bowyer, J.L.; Shmulsky, R.; Haygreen, J.G. 2007. Forest Products and Wood Science: An introduction. 2007. $5^{\text {th }}$ ed., Blackwell Publishing, Iowa.

Hietala, S.; Maunu, S.L.; Sundholm, F.; Jämsa, S.; Viitaniemi, P. 2002. Structure of thermally modified wood studied by liquid state NMR measurements. Holzforschung 56 (5): 522-528.

IAWA. 1989. List of microscopic features for hardwood identification. IAWA Bulletin 10: 219-332.

Lengowski, E. C. 2011. Efeito da termorretificação nas propriedades anatômicas, físico-mecânicas e químicas das madeiras de Pinus taeda, Eucalyptus grandis e Tectona grandis. Monography, Universidade Federal do Paraná, Curitiba, Brazil.

Mburu, F.; Dumarçay, S.; Huber, F.; Pétrissans, M.; Gérardin, P. 2007. Evaluation of thermally modified Grevillea robusta heartwood as an alternative to shortage of wood resource in Kenya: characterization of physicochemical properties and improvement of bio-resistance. Bioresource Technology 98 (18): 3478-3486.

Nicholls, J.W.P.; Dadswell, H.E. 1962. Tracheid length in Pinus radiata D. Don. CSIRO Div. Forest Products. Technical Paper 24. 
Ribeiro -Júnior, J.I. 2001. Análises estatísticas no SAEG. Universidade Federal de Viçosa, Viçosa. Spiegel, M.R. 1994. Estatística. 3rd. ed., Pearson Education do Brasil, São Paulo.

Tsoumis, G. 1991. Science and Technology of Wood: Structure, properties, utilization. Chapman \& Hall, New York.

Winandy, J.E.; Rowell, R.M. 1984. The Chemistry of Wood Strength. In: ROWELL, R.M. (editor). The Chemistry of Solid Wood. American Chemical Society, Washington. 